\title{
PENGARUH KOMBINASI SARIPATI BUAH NANAS DAN PEPAYA TERHADAP KUALITAS FISIK DAGING ITIK PETELUR AFKIR
}

\author{
The Effect of Combination of Pineaple and Papaya Fruit Quintessence on Physical Quality of Laying \\ Duck Meat
}

\author{
Anisa Ramadhani, Rr Riyanti, Veronica Wanniatie, Dian Septinova
}

Departemen of Animal Husbandry, Faculty of Agriculture, University of Lampung Jl Prof Dr Soemantri Brojonegoro No. 1 Gedung Meneng Bandar Lampung 35145 e-mail : anisaramadhani751@gmail.com

\begin{abstract}
This research aimed to determine the effect of combination of pineapple and papaya fruit quintessence on $\mathrm{pH}$, water holding capacity, and tenderness of meat of post production of laying duck. This research was conducted in December 2019 to January 2020 at Production and Reproduction of Livestock Laboratory, and Instrument Laboratory, Faculty of Agriculture University of Lampung. The materials of this research used were 20 pieces thigh meat of post production of laying duck. This research used a Completely Randomized Design (CRD) with 4 treatments and 5 replications. The treatment were without marination of combination of pineapple and papaya fruit (P0), marination with $25 \%$ pineapple $+75 \%$ papaya $(\mathrm{P} 1)$, marination with $50 \%$ pineapple $+50 \%$ papaya $(\mathrm{P} 2)$, and marination with $75 \%$ pineapple $+25 \%$ papaya $(\mathrm{P} 3)$. The variables observed were $\mathrm{pH}$ value, water holding capacity (WHC), and tenderness of laying duck meat. The data obtained were then analyzed by using variance analysis at 5\% level, the result of which had significant effect were continued tested using the Least Significance Different (BNT). The results of the analysis of variance showed that the addition of laying duck meat with a combination of pineapple and papaya fruit quintessence did not effect $(\mathrm{P}>0,05)$ on physical quality of meat of post production of laying duck.
\end{abstract}

Keywords: Laying duck meat, Papaya, Pineapple, Physical quality

\begin{abstract}
ABSTRAK
Penelitian ini bertujuan untuk mengetahui pengaruh kombinasi saripati buah nanas dan pepaya terhadap $\mathrm{pH}$, daya ikat air, dan keempukan daging itik petelur afkir. Penelitian ini dilaksanakan pada Desember 2019 hingga Januari 2020 di Laboratorium Produksi Ternak, Jurusan Peternakan dan Laboratorium Instrumen Jurusan Teknologi Hasil Pertanian, Fakultas Pertanian, Universitas Lampung. Materi penelitian menggunakan 20 potong bagian paha itik petelur afkir. Penelitian ini menggunakan Rancangan Acak Lengkap (RAL) dengan 4 perlakuan dan 5 ulangan yaitu tanpa marinasi kombinasi saripati buah nanas dan pepaya (P0), marinasi $25 \%$ nanas $+75 \%$ pepaya $(\mathrm{P} 1)$, marinasi $50 \%$ nanas $+50 \%$ pepaya $(\mathrm{P} 2)$, dan marinasi $75 \%$ nanas $+25 \%$ pepaya (P3). Peubah yang diamati adalah nilai $\mathrm{pH}$, daya ikat air (DIA), dan keempukan. Data yang diperoleh kemudian dianalisis ragam dengan taraf nyata $5 \%$, hasil yang berpengaruh nyata diuji lanjut menggunakan Beda Nyata Terkecil (BNT). Hasil analisis ragam menunjukkan bahwa penambahan daging itik dengan kombinasi saripati buah nanas dan pepaya tidak memberikan pengaruh yang nyata $(\mathrm{P}>0,05)$ terhadap $\mathrm{pH}$, daya ikat air, dan keempukan daging itik petelur afkir.
\end{abstract}

Kata kunci: Itik afkir, Kualitas fisik, Nanas, Pepaya

\section{PENDAHULUAN}

Pentingnya kebutuhan gizi khususnya protein hewani serta kesadaran masyarakat akan gizi yang baik terus meningkat setiap tahunnya sebanding dengan peningkatan jumlah penduduk. Kebutuhan gizi tersebut khususnya protein hewani dapat diperoleh dengan mengonsumsi produkproduk peternakan seperti susu, daging, dan telur. Pemenuhan gizi dari protein hewani sendiri akan memberikan dampak yang baik terhadap kesehatan, pertumbuhan, kecerdasan, dan kekuatan fisik.

Daging mengandung gizi lengkap seperti protein, air, energi, vitamin, dan mineral sehingga keseimbangan gizi untuk hidup dapat dipenuhi. Daging unggas merupakan salah satu produk ternak yang banyak digemari oleh masyarakat dibanding jenis daging lain yang beredar di pasaran. Hal tersebut didasarkan pada banyaknya kandungan nutrisi serta harga yang cenderung lebih murah dibandingkan daging sapi atau kambing. Unggas yang sampai saat ini populer di masyarakat adalah ayam, tetapi masih ada jenis unggas lain yang mempunyai potensi cukup besar untuk dikembangkan sebagai penghasil daging yaitu itik. Dirjennak (2019) melaporkan bahwa peran itik sebagai penghasil daging masih rendah, pada 2018 produksi itik sebesar 44.059 ton dengan kebutuhan konsumsi daging itik nasional mencapai 663.290 ton.

Salah satu alternatif untuk memenuhi kebutuhan akan ketersediaan dan konsumsi daging, dapat dilakukan dengan memanfaatkan protein 
daging itik petelur afkir. Produk itik lokal yang telah dikenal masyarakat baru terbatas pada telurnya, sedangkan dagingnya masih kurang disukai karena dianggap keras. Hal ini disebabkan oleh semakin tua umur ternak, maka jumlah jaringan ikat lebih banyak, sehingga meningkatkan keliatan tekstur daging.

Beberapa metode dilakukan untuk meningkatkan keempukan daging itik afkir baik melalui metode pemasakan maupun penambahan enzim. Metode pengempukan melalui cara pemasakan biasanya menggunakan energi panas untuk menjadikan daging menjadi lebih empuk. Metode ini memiliki kekurangan yaitu penggunaan panas yang berlebih dalam pemasakan akan menyebabkan kerusakan asam amino yang terkandung dalam daging terutama lisin, sedangkan pada metode penambahan enzim pengempuk mengalami kelebihan distribusi enzim yang dapat mempengaruhi seluruh organ, jaringan, dan perototan sehingga keempukan akan lebih efektif dan merata.

Penggunaan metode enzim dalam proses pengempukan daging sendiri biasanya memanfaatkan enzim golongan protease. Salah satunya bromelin dan papain. Buah nanas mengandung enzim bromelin yaitu golongan protease yang dapat menyerang jaringan ikat protein, mendegradasinya, dan selanjutnya memberikan efek empuk pada daging. Pada pepaya terdapat enzim papain dan kimopapain yang merupakan enzim protease yang juga memiliki kemampuan untuk mengempukkan daging dengan menyerang protein pada serat-serat otot (muscle fiber) dan menghidrolisisnya menjadi peptide yang lebih kecil (Murtini dan Qomarudin, 2002). Perbedaan kemampuan inilah yang menjadikan kombinasi saripati buah nanas dan pepaya dipercaya mampu bekerja secara bersama dan kompleks dalam mengempukkan daging. Penggunaan enzim bromelin dan papain dapat diterapkan oleh masyarakat umum secara praktis mengingat pohon nanas dan pepaya hampir tersebar di semua daerah dan mudah didapat, didukung hasil penelitian Utami et al. (2011) bahwa terdapat peningkatan keempukan, $\mathrm{pH}$, daya ikat air, dan penurunan susut masak daging itik dengan penambahan $15 \%$ ekstrak buah nanas dan waktu pemasakan 60 menit. Hasil penelitian Ismanto dan Basuki (2017) menunjukkan bahwa penambahan $0,5,10$, dan $15 \mathrm{ml} / 100 \mathrm{~g}$ daging belum mampu mempengaruhi $\mathrm{pH}$ dan daya ikat air. Hasil penelitian Krisnaningsih dan Yulianti (2015) menunjukkan bahwa penambahan kombinasi ekstrak buah nanas dan pepaya dapat meningkatkan keempukan daging itik petelur dengan hasil penilaian tertinggi dari panelis pada kombinasi $25 \%$ nanas; $75 \%$ pepaya sebesar 30,15 , sehingga diperlukan penelitian dengan level serupa untuk melihat efektivitas nanas dan pepaya dalam mempengaruhi keempukan daging. Berdasarkan uraian di atas, maka perlu dilakukan penelitian untuk mengetahui pengaruh kombinasi saripati buah nanas dan pepaya terhadap kualitas fisik daging itik petelur afkir terutama $\mathrm{pH}$, daya ikat air, dan keempukan daging.

\section{MATERI DAN METODE}

Penelitian ini dilaksanakan pada Januari 2020 di Laboratorium Produksi Ternak, Jurusan Peternakan dan Laboratorium Instrumen Jurusan Teknologi Hasil Pertanian, Fakultas Pertanian, Universitas Lampung.

\section{Materi}

Bahan yang digunakan pada penelitian ini yaitu larutan kombinasi saripati buah nanas dan pepaya yang berasal dari hasil penyaringan buah nanas Queen dan pepaya Jingga muda, akuades, dan daging itik petelur afkir jenis Hibrida umur 27 bulan bagian paha. Alat yang digunakan pada penelitian ini yaitu pisau, talenan, timbangan analitik, label, parutan, $\mathrm{pH}$ meter, wadah plastik, baskom, nampan, besi pemberat, kaca plat ukuran $25 \times 25 \mathrm{~cm}$, kertas saring ukuran $5 \times 5 \mathrm{~cm}$, mortar alu, texture analyzer, penjepit, kain lap, dan alat tulis.

\section{Metode \\ Rancangan percobaan}

Penelitian menggunakan metode Rancangan Acak Lengkap (RAL) dengan 4 perlakuan dan 5 ulangan. Perlakuan yang diberikan antara lain kontrol (P0), daging itik $+25 \%$ nanas $+75 \%$ pepaya (P1), daging itik $+50 \%$ nanas $+50 \%$ pepaya (P2), dan daging itik $+75 \%$ nanas $+25 \%$ papaya (P3).

\section{Pelaksanaan penelitian}

Pelaksanaan penelitian ini diawali dengan pembuatan larutan kombinasi saripati buah nanas dan pepaya dimulai dengan memilih buah nanas dan pepaya muda, lalu dikupas kulitnya dan dicuci hingga bersih, buah dipotong-potong untuk memudahkan proses penghalusan. Selanjutnya diperas dan disaring untuk dapat dipisahkan ampas dan saripati buah lalu dibuat sesuai dengan komposisi larutan yaitu $25 \%$ buah nanas $+75 \%$ buah pepaya ( $25 \mathrm{ml}$ saripati buah nanas $+75 \mathrm{ml}$ saripati buah pepaya); $50 \%$ buah nanas $+50 \%$ buah pepaya $(50 \mathrm{ml}$ saripati buah nanas $+50 \mathrm{ml}$ saripati buah pepaya); $75 \%$ buah nanas $+25 \%$ buah pepaya $(75 \mathrm{ml}$ saripati buah nanas $+25 \mathrm{ml}$ saripati buah pepaya); kemudian dimasukkan ke dalam wadah plastik. Daging itik yang digunakan yaitu bagian paha, karena bagian ini banyak digunakan untuk bergerak sehingga lebih liat dibanding bagian lain. Daging itik kemudian dimarinasi dengan kombinasi saripati buah nanas dan pepaya sesuai perlakuan selama 45 menit kemudian ditiriskan dan diamati $\mathrm{pH}$, daya ikat air, dan keempukannya.

\section{Peubah yang diamati}

Peubah yang diamati dalam penelitian ini adalah $\mathrm{pH}$, daya ikat air, dan keempukan daging itik petelur afkir. Pengukuran $\mathrm{pH}$ daging dimulai dengan kalibrasi $\mathrm{pH}$ meter, pembilasan elektroda dengan akuades dan pengeringan. Lalu sampel daging dihaluskan dan ditimbang seberat 10 gram dan dicampur dengan $40 \mathrm{ml}$ akuades dan 
dihomogenkan. Selanjutnya elektroda dicelupkan ke dalam sampel dan dibaca nilai pH-nya (AOAC, 1984).

Pengukuran daya ikat air dilakukan dengan menimbang sampel 0,28-0,32 gram dan diletakkan pada kertas saring berukuran $5 \times 5 \mathrm{~cm}$ diantara dua kaca datar $(25 \times 25 \mathrm{~cm})$, pemberat seberat 10 kilogram diletakkan di atas kaca dan dibiarkan selama 5 menit lalu ditimbang kembali dan dihitung dengan rumus:

$\% \mathrm{DIA}=100 \%-[(\mathrm{W} 0-\mathrm{W} 1) / \mathrm{W} 0) \times 100 \%]$

Keterangan:

W0 : berat awal

W1 : berat akhir (Kissel et al., 2009)

Pengukuran keempukan dimulai dengan penyiapan alat texture analyzer dan daging diletakkan tepat di bawah probe silinder. Lalu dikaitkan dengan probe pada ujung sampel dan dibaca hasil pengukuran dimana angkanya tertera pada texture analyzer (Farida et al., 2006).

\section{Analisis data}

Data yang diperoleh dianalisis dengan Analisis of Variance (ANOVA). Hasil analisis yang berpengaruh nyata pada suatu peubah dianalisis lanjut dengan Uji Beda Nyata Terkecil (BNT) pada taraf nyata $5 \%$.

\section{HASIL DAN PEMBAHASAN}

\section{Nilai pH Daging Itik Petelur Afkir}

Rata-rata nilai $\mathrm{pH}$ daging setelah diberi perlakuan yang diperoleh berdasarkan penelitian disajikan pada Tabel 1. Rata-rata nilai $\mathrm{pH}$ daging setelah dimarinasi dalam larutan kombinasi saripati buah nanas dan pepaya yaitu sebesar 6,12-6,76. Hasil analisis ragam menunjukkan bahwa perlakuan yang diberikan tidak berbeda nyata $(\mathrm{P}>0,05)$ terhadap $\mathrm{pH}$ daging itik petelur afkir.

Tabel 1. Rata-rata $\mathrm{pH}$ daging itik petelur afkir dengan pemberian kombinasi saripati buah nanas dan pepaya.

\begin{tabular}{ccccc}
\hline \multirow{2}{*}{ Ulangan } & \multicolumn{3}{c}{ Perlakuan } & \\
\cline { 2 - 5 } & $\mathrm{P} 0$ & $\mathrm{P} 1$ & $\mathrm{P} 2$ & $\mathrm{P} 3$ \\
\hline 1 & 6,39 & 6,22 & 6,27 & 6,32 \\
2 & 6,36 & 6,40 & 6,40 & 6,35 \\
3 & 6,44 & 6,17 & 6,33 & 6,12 \\
4 & 6,28 & 6,25 & 6,25 & 6,37 \\
5 & 6,24 & 6,76 & 6,26 & 6,27 \\
\hline Rata-rata & 6,34 & 6,36 & 6,30 & \\
\hline
\end{tabular}

Keterangan: P0 : Daging itik afkir tanpa marinasi kombinasi nanas dan pepaya

$\mathrm{P} 1$ : Daging itik afkir $+25 \%$ nanas $+75 \%$ pepaya

P2 : Daging itik afkir $+50 \%$ nanas $+50 \%$ pepaya

P3 : Daging itik afkir $+75 \%$ nanas $+25 \%$ pepaya

Pemberian kombinasi saripati buah nanas dan pepaya yang tidak memberikan pengaruh nyata pada nilai $\mathrm{pH}$ daging diduga karena adanya peristiwa osmosis isotonik atau tidak adanya gerakan pada pertukaran air antara sel. Osmosis sendiri merupakan pertukaran air antara sel dengan lingkungan karena perbedaan konsentrasi (Kuntoro et al., 2007). Konsentrasi pada larutan kombinasi saripati buah nanas dan pepaya tidak dapat masuk ke dalam daging dan memberikan pengaruh pada $\mathrm{pH}$ daging itik petelur afkir. Hal tersebut sesuai dengan pendapat Maulana (2015) yang menyatakan bahwa konsentrasi air di dalam sel sama dengan yang ada di luar sel menyebabkan tidak terjadi gerakan apa-apa yang merupakan bentuk osmosis isotonik.

Nilai $\mathrm{pH}$ yang hampir sama pada tiap perlakuan juga diduga karena kerja enzim papain yang belum mampu bekerja mengubah $\mathrm{pH}$ dalam waktu 45 menit. Kemungkinan enzim papain yang diperoleh dari saripati buah pepaya memerlukan waktu yang lebih lama untuk dapat mempengaruhi $\mathrm{pH}$ daging. Hal tersebut sesuai dengan pendapat Ismanto dan Basuki (2017) bahwa penggunaan enzim papain tidak mengubah $\mathrm{pH}$ bahan secara drastis. Adanya sifat enzim dimana kecepatan aktivitasnya menurun jika mendekati konsentrasi jenuh enzim dan substrat menghasilkan percepatan hidrolisis yang tetap (Sudrajat, 2003). Selain pengaruh kinerja papain yang belum sempurna, nilai $\mathrm{pH}$ daging yang relatif sama antar perlakuan kemungkinan karena daging itik yang dijadikan sebagai bahan percobaan merupakan daging unggas yang termasuk dalam daging gelap. Daging gelap pada itik diduga memiliki nilai $\mathrm{pH}$ yang cenderung berbeda dengan daging unggas berwarna cerah seperti ayam. Hal tersebut dijelaskan Soeparno (2015) bahwa daging itik termasuk dalam daging gelap karena sebagian besar komposisinya terdiri atas serat-serat merah. Komariah et al. (2004) menambahkan bahwa warna yang lebih gelap dari warna normal daging memperlihatkan tingginya $\mathrm{pH}$. Septinova et al. (2016) juga menyatakan bahwa daging yang gelap memiliki $\mathrm{pH}$ diatas 6,0 sehingga kondisi ini menurunkan waktu simpan daging meskipun dilakukan pengemasan vakum.

Nilai $\mathrm{pH}$ daging yang dianjurkan oleh Standar Nasional Indonesia (2009) yaitu 5,6-6,5. Berdasarkan hasil tersebut dapat dipastikan bahwa nilai $\mathrm{pH}$ masih menunjukkan batas yang dianjurkan karena masih berada pada kisaran Standar Nasional Indonesia. Kesamaan nilai $\mathrm{pH}$ pada tiap perlakuan juga dapat dikarenakan jumlah glikogen yang relatif sama, mengingat bahwa perlakuan itik sebelum pemotongan sama dan umur yang digunakan juga sama. Nilai $\mathrm{pH}$ yang didapat pada penelitian ini termasuk di atas $\mathrm{pH}$ ultimat daging 
$(6,12-6,76)$. Pada umumnya kisaran $\mathrm{pH}$ ultimat daging segar berkisar 5,4-5,8 (Lawrie, 2003). Septinova et al. (2016) menambahkan bahwa $\mathrm{pH}$ akhir otot menjadi asam ( $\mathrm{pH}$ ultimat) setelah rigor mortis terbentuk secara sempurna, tapi kebanyakan yang terjadi adalah rigor mortis sudah terbentuk tetapi $\mathrm{pH}$ masih diatas $\mathrm{pH}$ akhir yang normal $(\mathrm{pH}>5,5-5,8)$.

Menurut Judge et al. (1989), tercapainya $\mathrm{pH}$ ultimat daging karena timbunan asam laktat pada saat glikolisis postmortem tergantung pada jumlah cadangan glikogen otot pada saat pemotongan. Penimbunan asam laktat akan berhenti setelah cadangan glikogen otot habis atau setelah kondisi yang tercapai yaitu $\mathrm{pH}$ cukup rendah untuk menghentikan enzim-enzim glikolitik dalam proses glikolisis anaerobik. Pengukuran $\mathrm{pH}$ pada penelitian ini dilakukan setelah 10 jam pasca pemotongan, sehingga diduga cadangan glikogen otot belum habis dan menghasilkan $\mathrm{pH}$ otot berkisar antara 6,12-6,76.
Daya Ikat Air (DIA) Daging Itik Petelur Afkir

Hasil penelitian ini menunjukkan nilai daya ikat air daging itik petelur afkir setelah diberi perlakuan marinasi kombinasi saripati buah nanas dan pepaya sebesar $54,84-68,75 \%$. Hasil analisis ragam menunjukkan bahwa perlakuan marinasi kombinasi saripati buah nanas dan pepaya pada komposisi yang berbeda menunjukkan hasil yang tidak berbeda nyata $(\mathrm{P}>0,05)$ terhadap DIA. Hal ini diduga karena nilai $\mathrm{pH}$ daging tidak berbeda nyata pada semua perlakuan. Nilai $\mathrm{pH}$ memiliki keterkaitan dengan DIA daging yang juga tidak memberikan pengaruh nyata dan cenderung tinggi. Tingginya $\mathrm{pH}$ daging dapat menyebabkan DIA menjadi tinggi. Hal tersebut sesuai dengan pendapat Pearson dan Young (1989) yang menyatakan bahwa daya ikat air akan meningkat jika nilai $\mathrm{pH}$ daging meningkat.

Tabel 2. Rata-rata DIA daging itik petelur afkir dengan pemberian kombinasi saripati buah nanas dan pepaya.

\begin{tabular}{ccccc}
\hline \multirow{2}{*}{ Ulangan } & \multicolumn{3}{c}{ Perlakuan } \\
\cline { 2 - 5 } & $\mathrm{P} 0$ & $\mathrm{P} 1$ & $\mathrm{P} 2$ & $\mathrm{P} 3$ \\
\hline 1 & 56,66 & 64,51 & 54,84 & 68,75 \\
2 & 63,33 & 58,06 & 61,29 & 64,52 \\
3 & 61,29 & 67,74 & 61,29 & 54,84 \\
4 & 58,06 & 54,83 & 58,06 & 61,29 \\
5 & 61,29 & 58,06 & 58,06 & 67,74 \\
\hline Rata-rata & 60,12 & 60,64 & 58,70 & 63,42 \\
\hline
\end{tabular}

Keterangan: P0 : Daging itik afkir tanpa marinasi kombinasi nanas dan pepaya

$\mathrm{P} 1$ : Daging itik afkir $+25 \%$ nanas $+75 \%$ pepaya

$\mathrm{P} 2$ : Daging itik afkir $+50 \%$ nanas $+50 \%$ pepaya

P3 : Daging itik afkir $+75 \%$ nanas $+25 \%$ papaya

Hasil penelitian pada $\mathrm{pH}$ daging menunjukkan bahwa nilai $\mathrm{pH}$ berada pada kisaran 6,12-6,76. Nilai tersebut termasuk dalam $\mathrm{pH}$ di atas isoelektrik $(\mathrm{pH}>5,2-5,4)$ sehingga mampu menjadikan daya ikat air pada daging tinggi. Hal tersebut menurut Soeparno (2015) disebabkan oleh $\mathrm{pH}$ yang lebih tinggi atau lebih rendah dari titik isoelektrik protein daging, dan menyebabkan daya ikat air meningkat. $\mathrm{pH}$ daging yang meningkat tersebut akan meningkatkan gugus reaktif proteinprotein daging yang menyebabkan banyak air daging terikat sehingga daya ikat air menjadi meningkat.

Pemberian marinasi kombinasi saripati buah nanas dan pepaya dalam komposisi yang berbeda tidak berbeda nyata $(\mathrm{P}>0,05)$ terhadap DIA daging itik petelur afkir yang diduga akibat penggunaan buah nanas muda pada penelitian dengan kandungan bromelin yang lebih rendah dibandingkan dengan buah nanas tua. Hal ini dinyatakan oleh Ferdiansyah (2005) dimana kandungan enzim bromelin yang ada pada buah nanas tua mencapai $0,060-0,080 \%$ sedangkan kandungan nanas muda hanya mencapai 0,040 $0,060 \%$.

Marinasi daging paha itik dengan kombinasi ekstrak buah nanas dan pepaya tidak berpengaruh nyata pada DIA daging itik yang juga diduga akibat adanya peristiwa osmosis yang berlangsung lambat, dimana air yang terdapat dalam daging terlepas keluar sehingga terjadi penurunan bobot daging. Lambatnya osmosis ini mungkin dikarenakan waktu marinasi yang singkat. Kemungkinan marinasi dalam waktu 45 menit belum mampu menjadikan proses osmosis berjalan pada seluruh permukaan yang menyebabkan saripati buah nanas dan pepaya tidak bekerja secara aktif mempengaruhi DIA. Hal tersebut sesuai dengan pendapat Pangestu (2015) yang menyatakan bahwa luas permukaan membran mempengaruhi kecepatan osmosis. Semakin luas permukaan maka proses osmosis akan semakin cepat. Lambatnya proses osmosis menyebabkan senyawa aktif dalam kombinasi saripati buah nanas dan pepaya tidak terpenetrasi dengan baik sehingga tidak dapat mempengaruhi DIA daging itik.

Nilai daya ikat air daging yang relatif sama (54,84-68,75\%) pada semua perlakuan diduga juga karena suhu ruangan penelitian yang dianggap rendah $\left(23^{\circ} \mathrm{C}\right)$, yang juga menjadi kemungkinan enzim papain dalam buah pepaya belum mampu memberikan pengaruh pada DIA daging. Hal tersebut dikarenakan enzim papain memiliki suhu optimum yang dapat membuatnya bekerja secara optimal terutama dalam mempengaruhi DIA daging. Hasil penelitian Kusumadjaja dan Dewi (2005) menunjukkan bahwa aktivitas enzim papain mengalami kenaikan seiring peningkatan suhu dari 
$32^{\circ}$ hingga $50^{\circ}$ dengan puncak kurva berada pada suhu $50^{\circ}$. Aktivitas ini akan mengalami penurunan apabila suhu lebih dari $50^{\circ}$. Hal tersebut diperkuat oleh pendapat Soeparno (2015) bahwa suhu rendah, enzim yang bekerja pada jahe dan getah pepaya tidak mengalami kerusakan sehingga enzim-enzim tersebut menghambat daya ikat air pada daging, sehingga daging tidak mampu mengikat air secara optimal.

\section{Keempukan Daging Itik Petelur Afkir}

Nilai rata-rata keempukan daging itik petelur afkir berkisar antara 101,75-560,25 (Tabel 3). Hasil analisis ragam menunjukkan bahwa marinasi kombinasi saripati buah nanas dan pepaya pada komposisi yang berbeda tidak menunjukkan perbedaan yang nyata $(\mathrm{P}>0,05)$ terhadap keempukan daging itik petelur afkir. Hal tersebut dapat dikarenakan aktivitas enzim bromelin yang rendah. Aktivitas enzim bromelin pada buah nanas memiliki nilai yang lebih rendah dibandingkan dengan batangnya. Aktivitas yang terbatas inilah yang memungkinkan saripati buah nanas dan pepaya belum mampu memberikan efek berbeda nyata pada keempukan daging itik petelur afkir. Hal tersebut sesuai dengan pendapat Gautam et al. (2010) yang menyatakan bahwa enzim bromelin yang diisolasi dari buah dan batang nanas memiliki aktivitas yang berbeda. Aktivitas enzim bromelin dari batang lebih tinggi yakni 3,500 GDU/gram, sedangkan enzim bromelin dari buah nanas hanya $1,500 \mathrm{GDU} /$ gram.

Tabel 3. Rata-rata keempukan daging itik petelur afkir dengan pemberian kombinasi saripati buah nanas dan pepaya.

\begin{tabular}{ccccc}
\hline \multirow{2}{*}{ Ulangan } & \multicolumn{4}{c}{ Perlakuan } \\
\cline { 2 - 5 } & P0 & P1 & P2 & P3 \\
\hline 1 & 268,25 & 220,00 & 183,00 & 217,75 \\
2 & 208,75 & 320,75 & 165,00 & 101,75 \\
3 & 362,00 & 406,5 & 360,25 & 125,75 \\
4 & 156,75 & 137,25 & 369,00 & 145,75 \\
5 & 215,50 & 110,50 & 457,75 & 227,55
\end{tabular}

Keterangan: P0 : Daging itik afkir tanpa marinasi kombinasi nanas dan pepaya

P1 : Daging itik afkir $+25 \%$ nanas $+75 \%$ pepaya

P2 : Daging itik afkir $+50 \%$ nanas $+50 \%$ pepaya

P3 : Daging itik afkir $+75 \%$ nanas $+25 \%$ pepaya

Hasil yang tidak berbeda nyata $(\mathrm{P}>0,05)$ pada uji keempukan daging itik petelur afkir juga diduga karena $\mathrm{pH}$ pada enzim papain yang kurang optimal. Hal tersebut dikarenakan $\mathrm{pH}$ memiliki keterikatan dengan aktivitas enzim. Wirahadikusumah (1981) menjelaskan bahwa nilai $\mathrm{pH}$ sangat berpengaruh terhadap aktivitas enzim. $\mathrm{pH}$ larutan yang diberikan pada saat penelitian terdiri atas perlakuan dua $(25 \%$ nanas + $75 \%$ pepaya), perlakuan tiga ( $50 \%$ nanas $+50 \%$ pepaya), dan perlakuan empat ( $75 \%$ nanas $+25 \%$ pepaya) memiliki nilai berturut-turut 6,054; 5,$009 ; 4,454$. Diduga pada $\mathrm{pH}$ tersebut papain belum bekerja dengan baik sehingga zat aktif dalam papain tidak memberikan pengaruh nyata pada keempukan daging. Hasil penelitian Kusumadjaja dan Dewi (2005) menunjukkan bahwa aktivitas papain mencapai nilai tertinggi pada $\mathrm{pH}$ 6. Sama halnya seperti enzim papain, bromelin memiliki $\mathrm{pH}$ optimal yang akan membuatnya bekerja dengan baik sehingga mampu mempengaruhi keempukan daging. Menurut Fajrin (2012), enzim bromelin pada $\mathrm{pH}$ optimum 6,5-7,0 mempunyai konformasi yang mantap dan aktivitas maksimal.

Selain pengaruh faktor $\mathrm{pH}$ yang tidak sesuai, hasil tidak berbeda nyata $(\mathrm{P}>0,05)$ pada uji keempukan daging itik petelur afkir juga diduga karena suhu pada saat penelitian diduga juga menjadi faktor hasil uji yang tidak berbeda nyata. Suhu ruangan pada saat penelitian yang rendah $\left(23^{\circ} \mathrm{C}\right)$ diduga menjadi penyebab enzim bromelin dan papain menjadi kurang aktif. Enzim bromelin dan papain memiliki suhu optimum untuk menjadikannya aktif sehingga mampu memberikan berbagai manfaat sesuai dengan kinerjanya. Hal tersebut didukung oleh pendapat Fajrin (2012) bahwa aktivitas bromelin optimum pada suhu $50^{\circ} \mathrm{C}$, diatas suhu tersebut keaktifan akan menurun. Sedangkan pada suhu optimal papain, hasil penelitian Kusumadjaja dan Dewi (2005) menunjukkan bahwa aktivitas papain mengalami kenaikan seiring dengan peningkatan suhu dari 32-50. Aktivitas maksimum dicapai pada suhu $50^{\circ}$ yaitu sebesar $2,469 \mathrm{U} / \mathrm{mL}$.

\section{SIMPULAN DAN SARAN}

\section{Simpulan}

Simpulan yang dapat diambil dari penelitian ini yaitu penambahan saripati buah nanas dan pepaya $(0 \%$ nanas $+0 \%$ pepaya, $25 \%$ nanas + $75 \%$ pepaya, $50 \%$ nanas $+50 \%$ pepaya, dan $75 \%$ nanas $+25 \%$ pepaya) tidak memberikan pengaruh nyata $(\mathrm{P}>0,05)$ terhadap $\mathrm{pH}$, daya ikat air, dan keempukan daging itik petelur afkir.

\section{Saran}

Berdasarkan pembahasan simpulan, maka disarankan untuk dilakukannya penelitian lebih lanjut mengenai marinasi daging itik petelur afkir dengan metode lainnya seperti pemasakan, penambahan waktu perendaman, dan penggunaan buah nanas muda sehingga menghasilkan nilai $\mathrm{pH}$, daya ikat air, dan keempukan daging itik yang lebih baik. 


\section{DAFTAR PUSTAKA}

AOAC(Association of Official Analytical Chemists). 1984. Official Method of Analysis. 12 th ed. Association of Official Analytical Chemists Washington DC.

Direktorat Jenderal Peternakan. 2019. Data Lima Tahun Subsektor Peternakan http://www.deptan.go.id/infeksekutif/nak/ pdfeisNAK2013/Pop Iti Prop 013. Diakses pada 3 November 2019.

Fajrin, E. 2012. Penggunaan Enzim Bromelin pada Pembuatan Minyak Kelapa(Cocos nucifera) Secara Enzimatis. Skripsi. Universitas Hasanuddin. Makassar.

Farida. D., H. Kusumaningrum., D. Wulandari, dan D. Indrasti. 2006. Analisa Laboratorium. Departemen Ilmu dan Teknologi Pangan IPB. Bogor.

Ferdiansyah, Venol. 2005. Pemanfaatan Kitosan dari Cangkang Udang sebagai Matriks Penyangga pada Imobilisasi Enzim Protease. Skripsi. Teknologi Hasil Perikanan, Fakultas Perikanan dan Ilmu Kelautan, Institut Pertanian Bogor. Bogor.

Gautam, S., S. K. Mishra, S., V. Dash., A. K. Goyal, and G. Rath. 2010. Comparative Study of Extraction, Purification and Estimation of Bromelain from Stem and Fruit of Pineapple Plant. India: Thai. $J$. Pharm. Sci. p.34.

Ismanto, A dan R. Basuki. 2017. Pemanfaatan Ekstrak Buah Nanas dan Buah Pepaya sebagai Bahan Pengempuk Daging Ayam Parent Stock Afkir. J. Peternakan Sriwijaya. 6: 2.

Judge, M.D., Aberle, J.C. Forrest, H.B. Hendrick, and R.A. Merkel. 1989. Principle of Meat Science. 2nd ed. Kendall Hunt Publishing Co., Dubuque, lowa.

Kissel, C. A. L. Soarest. A. Rossa and M. Shimokomaki. 2009. Functional properties of pse (pale, soft, exudative) broiler meat in the production of mortadella. Brazilian archives of Biol and Technol an Intern J. Vol 52: 213-217

Komariah, I., I. Arief, dan Y. Wiguna. 2004. Kualitas Fisik dan Mikrobia Daging Sapi yang Ditambah Jahe (Zinger officinaleroecoe) pada Konsentrasi dan Lama Penyimpanan Berbeda. Media Peternakan. 28 (2): 38-87.

Krisnaningsih, A. T. N dan D. L. Yulianti. 2015. Pemanfaatan Kombinasi Ekstrak Buah Nanas dan Pepaya untuk Meningkatkan Kualitas Daging Itik Petelur Afkir. $J$. Buana Sains. $15(01)$.

Kuntoro, B., I. Mirdhayati, dan T. Adelina. 2007. Penggunaan Ekstrak Daun Katuk (Sauropus androgunus I. Men) sebagai
Bahan Pengawet Alami Daging Sapi Segar. J. Peternakan. 4: 6-12.

Kusumadjaja, A. P dan R. P. Dewi. 2005. Penentuan Kondisi Optimum Enzim Papain dari Pepaya Burung Varietas Jawa (Carica papaya). Indo. J. Cem. 5(2): 147151.

Lawrie, R. A. 2003. Ilmu Daging. Penerjemah Aminuddin Parakkasi. Penerbit UI Press. Jakarta.

Maulana, A. 2015. Difusi dan Osmosis Pengertian dan Perbedaannya. http://www.informasibelajar.com/2015

08/difusi-dan-osmosis-pengertian dan perbedaan.html. Diakses pada 11 Februari 2020

Murtini, E. S dan Qomarudin. 2002. Penggemukan Daging Dengan Enzim Protease Tanaman Biduri (Calotropis gigantea). JTIP. 14(3): 266-268.

Pangestu, B. 2015. Faktor-Faktor yang Mempengaruhi Difusi dan Osmosis (Terlengkap).

http://www.biosend.id/205/08/faktor-yangmemengaruhi difusi-dan.html. Diakses pada 09 Februari 2020

Pearson, A.M. and R.B. Young. 1989. Meat and Biochemistry. Academy Press Inc. California.

Septinova, D., Riyanti, dan V. Wanniatie. 2016. Dasar Teknologi Hasil Ternak. Buku Ajar. Universitas Lampung.

Soeparno. 2015. Ilmu dan Teknologi Daging. Gadjah Mada University Press. Yogyakarta.

Sudrajat, A. 2003. Pengaruh Temperatur dan Lama Pemasakan terhadap Karakteristik Fisik dan Organoleptik Daging Ayam Broiler. Gadjah Mada University Press. Yogyakarta.

Wirahadikusumah, M. 1981. Biokimia Protein, Enzim dan Asam Nukleat terbitan ke2. ITB. Bandung. 